\title{
Ferulic Acid Depletion by Cultured Soybean Seedlings under Action of Glucose and Methionine
}

\author{
Vanessa Herrig, Hélio Cândido da Silva, Maria de Lourdes Lucio Ferrarese and Osvaldo \\ Ferrarese-Filho* \\ Department of Biochemistry, University of Maringá, 87020-900 Maringá - PR, Brazil
}

\begin{abstract}
Cultured soybean seedlings were used to investigate how glucose or methionine influenced depletion of ferulic acid. Three-day-old seedlings were grown in hydroponic solution containing ferulic acid plus glucose or methionine, and the level of the phenolic acid were monitored in the nutrient culture. The results showed that ferulic acid depletion was more rapid in the presence of those compounds. After $6 \mathrm{~h}$, the increase caused by glucose $(0.01$ and $0.05 \mathrm{mM})$ was more pronounced than methionine in the same concentrations. On the other hand, methionine $(0.1$ and $0.2 \mathrm{mM})$ increased depletion more significantly than glucose. Results suggested that both compounds might to increase the allelopathic effects of ferulic acid in the seedlings.
\end{abstract}

Key words: Glycine $\max$ L. Merr., root, phenolic acid, carbohydrate, aminoacid

\section{INTRODUCTION}

Phenolic acids including ferulic and $p$-coumaric acids constitute an important class of allelochemicals which are released into soil environment as root exudates, leaf leachates, and products of plant tissue decomposition (Einhellig, 1995). Allelochemicals active against higher plants are typically characterized as suppressing seed germination, causing injury to root growth, or inhibiting seedling growth. Furthermore, they alter water utilization and mineral uptake (Lyu and Blum, 1990; Hollapa and Blum, 1991; Bergmark et al. 1992), chlorophyll content and photosynthesis rates (Mersie and Singh, 1993), foliar expansion (Blum and Rebbeck, 1989), cell morphology (Liu and Lovett, 1993) and protein synthesis (Baziramakenga et al. 1997) among countless other actions.

Although physiological actions have been documented extensively in several species, limited attention has been given to evaluate how other organic molecules distributed in soils may alter phenolic acid toxicity. Research has suggested that allelopathic interactions involving phenolic acids under field conditions are most likely a result of mixtures of phenolic acids and other organic compounds (Blum, 1996). In this context, Blum et al. (1993) reported that glucose and methionine treatments influenced the inhibitory action of $p$ coumaric acid on biomass production of morning glory (Ipomoea hederacea L.) seedlings. Likewise, Pue et al. (1995) demonstrated that amounts of $p$ coumaric acid required for a given level of inhibition of shoot and seedling biomass accumulation decreased with glucose increase. Using the solution depletion technique (Shann and Blum, 1987), the objective of this work was to investigate how ferulic acid, in nutrient culture, was depleted by soybean roots under influence of glucose or methionine.

\section{MATERIALS AND METHODS}

General procedures: Soybean seeds (Glycine max L. Merrill cv. BR16, Sealcoop Co, Maringá, Brazil) were surface sterilized in a solution of $2 \%$ (v/v) sodium hypochlorite for two minutes and washed thoroughly with deionized water. The seeds were spread uniformly on paper towels, wrapped and transferred to plastic containers $(10 \mathrm{x}$

* Author for correspondence 
$16 \mathrm{~cm}$ ) with a small amount of deionized water in the bottom. The containers were incubated in a germination chamber (Tecnal TE 400, São Paulo, Brazil), in darkness. Air temperature was maintained at $25^{\circ} \mathrm{C}( \pm 0.2)$ and relative humidity ranged between 70 and $80 \%$.

Three-day-old seedlings of uniform size were transferred into containers and supplied with 200 $\mathrm{ml}$ of nutrient solution (Hoagland and Arnon, 1950) containing $0.1 \mathrm{mM}$ ferulic acid and glucose or methionine $(0.01$ to $0.2 \mathrm{mM})$. Nutrient solution was buffered with $17 \mathrm{mM}$ potassium phosphate and adjusted to $\mathrm{pH}$ 6.0. Each container held twenty-five seedlings suspended in the solution by floating styrofoam boats. The containers were kept in the growth chamber, at $25^{\circ} \mathrm{C}$, under fluorescent light $(6-20 \mathrm{~W})$ on a 12-hours dark/12-hours light cycle. The culture solutions were aerated continuously by air bubbling. Experiments were made in aseptic conditions and fungal infection was absent from all samples tested. Ferulic acid used in this investigation was purchased from Sigma Chemical Co (St. Louis, Missouri, USA). All other reagents were of analytical grades.

Ferulic acid depletion experiment: The ferulic acid concentration in nutrient culture was carried out by the depletion of this compound from the initial $200 \mathrm{ml}$ solutions (Shann and Blum, 1987). Ferulic acid in the samples was determined by Folin-Ciocalteau method. Samples $(2.0 \mathrm{ml})$ of the nutrient solution plus $3.0 \mathrm{ml}$ deionized water or $2.0 \mathrm{ml}$ of standard phenolic acid solution plus 3.0 $\mathrm{ml}$ deionized water were mixed with $0.75 \mathrm{ml}$ of $1.9 \mathrm{M} \mathrm{Na}_{2} \mathrm{CO}_{3}$ and $0.25 \mathrm{ml}$ of Folin-Ciocalteau phenol reagent. The mixture was allowed to stand in darkness at room temperature $\left(23^{\circ} \mathrm{C}-25^{\circ} \mathrm{C}\right)$ for one hour before its absorption was measured at $750 \mathrm{~nm}$ (Blum et al. 1991).

Data analysis. Data were analyzed using the InStat $^{\circledR}$ package (Version 1.12a, GraphPAD Software, USA, 1990). Statistical significance of the difference between parameters was evaluated by means of Student's $t$-test. The results are given in the text as $\mathrm{P}$, the probability values. The criterion of significance adopted was $\mathrm{P}<0.05$. All values were expressed as means of three to five independent replicates.

\section{RESULTS AND DISCUSSION}

Figure 1 (A or B) shows that the depletion of 0.1 $\mathrm{mM}$ ferulic acid in the absence of glucose (control) was linear up to 6 hours, and curvilinear after this time. Starting from 6 hours, the depleted amount reached its maximum with 24 hours and ceased at 30 hours. The same figure (1A) shows the ferulic acid depletion in the presence of 0.01 $\mathrm{mM}$ and $0.1 \mathrm{mM}$ glucose. As can be seen, carbohydrate affected the phenolic acid depletion. By comparison with $0.1 \mathrm{mM}$ glucose, depletion was more significantly altered with $0.01 \mathrm{mM}$ glucose $(\mathrm{P}=0.017$, paired test with the control) and this behavior was identical up to 30 hours.

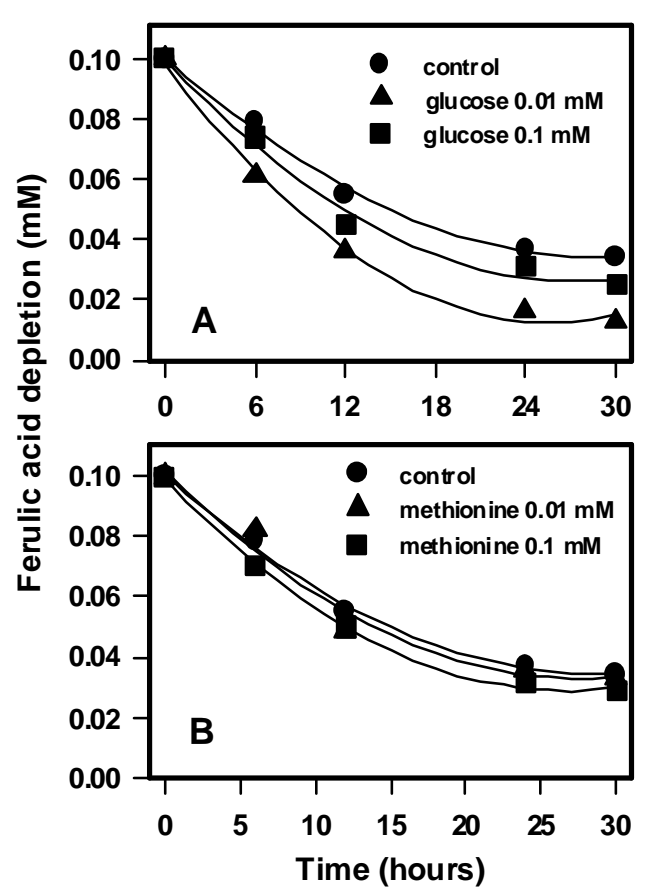

Figure 1 - Depletion of $0.1 \mathrm{mM}$ ferulic acid by soybean roots in the presence of glucose (A) or methionine (B) over time.

As revealed by Figure 1B, contrary to results obtained with glucose, depletion of the phenolic acid was unaffected by methionine over time. Comparison of means of control and experiments with methionine did not show any significant differences up to 30 hours as checked by Student's $t$-test $(\mathrm{P}>0.05$, paired test).

Although the experiments shown in this 
investigation have been carried out under aseptic conditions, it is possible that microbial or physicatchemical breakdown products in nutrient culture overestimate depletion results (especially with glucose) up to 30 hours. Furthermore, there is possibility of ferulic acid efflux from the seedling to the solution. However, in agreement with results of the present investigation, Shann and Blum (1987) reported that $0.1 \mathrm{mM}$ ferulic acid depletion by cucumber root was rapid up to 6 hours. In addition, they didn't detect any exudation of ferulic acid of the root into the nutrient solution but, after that time, microbial metabolic products of ferulic acid were detected in small amounts in the culture. Nevertheless, in order to eliminate this interference, additional experiments were performed up to 6 hours with glucose or methionine at different concentrations (Fig. 2).

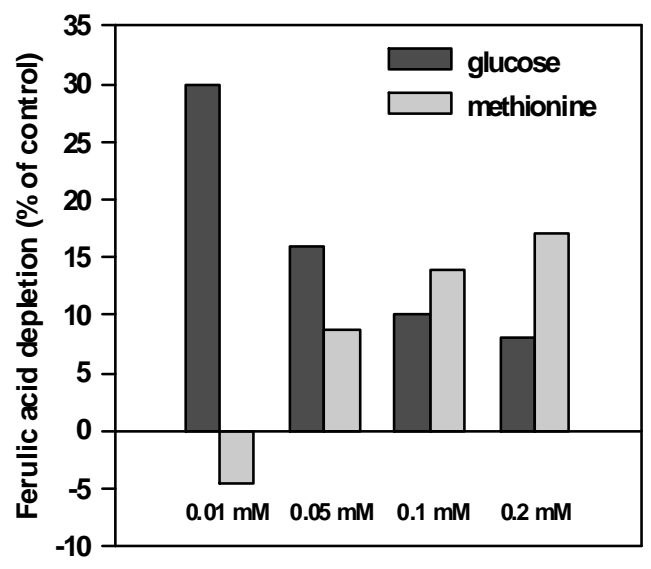

Figure 2 - Depletion of $0.1 \mathrm{mM}$ ferulic acid by soybean roots in the presence of glucose or methionine after 6 hours.

As can be seen in the figure above, glucose, at extremely low concentration $(0.01 \mathrm{mM})$, increased $30 \%$ the ferulic acid depletion in comparison to the control. Even so, above $0.01 \mathrm{mM}$, depletion also increased significantly. Between 0.05 and 0.2 $\mathrm{mM}$, this increase was $12 \%$, approximately. On the other hand, contrasting with the effects of glucose, $0.01 \mathrm{mM}$ methionine did not influence ferulic acid depletion. Statistical analyses showed that comparison of means of control with methionine were not significant at the 5\% probability level $(\mathrm{P}=0.263)$. However, compatible with results of glucose, statistical differences happened to concentrations above $0.05 \mathrm{mM}$. As revealed by data, $0.2 \mathrm{mM}$ methionine increased substantially the ferulic acid depletion in comparison to the control $(17 \%, \mathrm{P}=0.03)$.

In summary, the results of the present investigation showed that both glucose and methionine increased $0.1 \mathrm{mM}$ ferulic acid depletion by roots in nutrient culture. The increase caused by glucose $(0.01$ and $0.05 \mathrm{mM})$ was more pronounced than methionine in the same concentrations. On its side, methionine ( 0.1 and $0.2 \mathrm{mM}$ ) increased depletion more significantly than glucose. Although these results were clearly verified, the underlying physiological mechanisms are still unknown.

Based on their studies with cucumber in soil infested with microbes, Blum et al. (1993) reported that to obtain a $10 \%$ inhibition of seedling biomass less $p$-coumaric acid was required when a second carbon source (glucose or methionine) was added. The authors suggested that the sites and/or modes of action of these compounds are different. For glucose, they hypothesized that its addition reduced the microbial utilization and/or sorption of $p$-coumaric acid in the soil and thus increased the effective concentration of the phenolic acid. For methionine, it has been demonstrated that the presence of this amino acid in soil did not affect the rate of $p$-coumaric acid utilization by microbes (Pue et al. 1995).

Differently of the methodology applied to the experiments described above, results of the present investigation were obtained without influence of microbes in nutrient solution. Then, it is reasonable to suppose that glucose or methionine may increase the allelopathic effects of ferulic acid since they increased its depletion. Furthermore, it is possible to speculate that these compounds influence ferulic acid uptake by roots. If this idea is correct, glucose or methionine may increase the phenolic acid consumption by roots, its disposability and, consequently, its effects on seedlings. Evidently, this is a hypothesis and a conclusive answer depends on further experiments evaluating the glucose (or methionine) and ferulic acid depletions as well as the presence of these compounds in roots. In this context, experiments using the HPLC technique to quantify ferulic acid, glucose and methionine in soybean roots are in progress. 


\section{RESUMO}

Plântulas de soja cultivadas em meio nutriente foram utilizadas para investigar como glicose ou metionina influenciam a depleção de ácido ferúlico. Plântulas de três dias foram cultivadas em meio hidropônico contendo ácido ferúlico e glicose ou metionina e os níveis de ácido ferúlico foram monitorados no meio nutriente. Os resultados mostraram que as raízes de soja depletaram ácido ferúlico mais rapidamente na presença dos compostos. Após 6 horas, o aumento causado pela glicose $(0,01$ e $0,05 \mathrm{mM})$ foi mais pronunciado que na presença de metionina, nas mesmas concentrações. Por seu lado, metionina, a 0,1 e 0,2 mM, aumentou a depleção mais significativamente que a glicose. Os resultados sugerem que ambos os compostos podem aumentar os efeitos alelopáticos do ácido ferúlico nas plântulas.

\section{REFERENCES}

Baziramakenga, R; Leroux, G.D.; Simard, R.R. \& Nadeau, P. (1997), Allelopathic effects of phenolic acids on nucleic acid and protein levels in soybean seedlings. Can. J. Bot., 75, 445-450

Bergmark C.; Jackson W.A.; Volk R.J. \& Blum U. (1992), Differential inhibition by ferulic acid of nitrate ammonium uptake in Zea mays L. Plant Physiol., 98, 639-645

Blum, U. (1996), Allelopathic interactions involving phenolic acids. J. Nemat., 28, 259-267

Blum, U. \& Rebbeck, J. (1989), Inhibition and recovery of cucumber roots given multiple treatments of ferulic acid in nutrient culture. J. Chem. Ecol., 15, 917-928

Blum, U.; Wentworth, T.R.; Klein, K.; Worsham, A.D.; King, L.D.; Gerig, T.M. \& Lyu, S.W. (1991), Phenolic acid content of soils from wheat-no till, wheat-conventional till, and fallow-conventional till soybean cropping systems. J. Chem. Ecol., 17, 10451068

Einhellig F.A. (1995), Allelopathy: Current status and future goals. In: Allelopathy. Organisms, Processes and Applications. ACS Simposium, Washington, ed. Inderjit; K.M.M.; Dakshimi \& F.A. Einhellig. American Chemical Societies, Series 582, New York. pp. 1-24

Hoagland, D.R. \& Arnon, D.I. (1950), The waterculture method of growing plants without soil. Calif. Agric. Exp. Stat. Cir., 347

Hollapa, L.D. \& Blum, U. (1991), Effects of exogenously applied ferulic acid, a potential allelopathic compound, on leaf growth, water utilization, and endogenous abscisic acid evels of tomato, cucumber, and bean. J. Chem. Ecol., 17, 865886

Liu, D.L. \& Lovett, J.V. (1993), Biologically active secondary metabolites of barley. II. Phytotoxicity of barley allelochemicals. J. Chem. Ecol., 19, 2231-2244

Lyu, S.W. \& Blum U. (1990), Effects of ferulic acid, an allelopathic compound, on net $\mathrm{P}, \mathrm{K}$, and water uptake by cucumber seedlings in a split-root system. $J$. Chem. Ecol., 16, 2429-2439

Mersie, W. \& Singh, M. (1993), Phenolics acids affect photosynthesis and protein synthesis by isolated leaf cells of velvet-leaf. J. Chem. Ecol., 19, 1293-1301

Pue K.J.; Blum, U.; Gerig, T.M. \& Shafer, S.R. (1995), Mechanism by which noninhibitory concentrations of glucose increase inhibitory activity of $p$-coumaric acid on morning-glory seedling biomass accumulation. J. Chem. Ecol., 21, 833-847

Shann, J.R. \& Blum, U. (1987), The uptake of ferulic acid and $p$-hydroxybenzoic acids by Cucumis sativus. Phytochem., 26, 2959-2964

Received: September 16, 1999; Revised: December 29, 1999; Accepted: February 17, 2000. 